Research Article

\title{
CORRELATION AND GENETIC VARIABILITY STUDIES IN GROUNDNUT (Arachis hypogaea L.) GENOTYPES
}

\section{GONYA NAYAK P., VENKATAIAH M., REVATHI P. AND SRINIVAS B.}

Division of Groundnut Research Scheme, Regional Agricultural Research Station, Professor Jayashankar Telangana State Agricultural University, Polasa, 505529 , Jagtial, Telangana.

*Corresponding Author: Email- pgonyanayak@gmail.com

Received: February 16, 2018; Revised: March 19, 2018; Accepted: March 22, 2018; Published: March 30, 2018

\begin{abstract}
The present experiment was conducted with 15 groundnut genotypes to estimate the genetic variability and correlation for yield and its components. Analysis of variance clearly specified the existence of ample amount of variability in present experimental material for improvement. Variability studies indicated the higher scope of selection in desirable direction for number of pods per plant, shelling percentage, hundred kernel weight, hundred pod weight, dry pod yield per hectare and kernel yield as they recorded higher GCV and genetic advance values. These traits were found to be governed by additive genes as evident by recording higher values for both heritability and genetic advance. Correlation studies revealed the simultaneous improvement of hundred pod weight, sound mature kernels and hundred kernel weights for improvement of the yield.
\end{abstract}

Keywords- Correlation, genetic variability, genetic advance, Groundnut.

Citation: Gonya Nayak P., et al., (2018) Correlation and Genetic Variability Studies in Groundnut (Arachis hypogaea L.) Genotypes. International Journal of Genetics, ISSN: 0975- 2862 \& E-ISSN: 0975-9158, Volume 10, Issue 2, pp.-354-356. DOI: http://dx.doi.org/10.9735/0975-2862.10.2.354-356

Copyright: Copyright@2018 Gonya Nayak P., et al., This is an open-access article distributed under the terms of the Creative Commons Attribution License, which permits unrestricted use, distribution and reproduction in any medium, provided the original author and source are credited.

\section{Introduction}

Groundnut is an important edible oilseed crop in Telangana and India. In Telangana it is grown in about 2 lakh hectare area in which $85 \%$ of the area is under rabi (irrigated) cultivation and production is about 1.45 lakh tones, However, per hectare yield is very low compared to other countries like USA, brazil and mayanmar (16.00lakh tones [1]. The reasons for low yield are incidence of late leaf spot, rust, stem rot and drought at pod development stage of the crop. To step up groundnut yields per unit area and per unit time, there is a need to develop high yielding varieties with resistance to biotic and abiotic stresses. Information on the phenotypic and genotypic relationships of pod yield in groundnut with its component characters and also among the characters themselves would be very useful to the breeder in developing an appropriate breeding strategy since pod yield is a complex character and is influenced by number of traits. Hence selection of genotypes with desirable characters would be greatly enhanced if significant correlation between yield and its component characters are established.

\section{Material and Methods}

During rabi 2015-16, fifteen groundnut genotypes were grown in randomized complete block design in three replications in $5 \mathrm{~m}$ length rows with spacing of 30 $\mathrm{cm}$ between the rows and $10 \mathrm{~cm}$ between the plants at Regional Agricultural Research Station, Jagtial. The crop was fertilized with $20 \mathrm{~N}, 40 \mathrm{P}_{2} \mathrm{O}_{5}$ and $50 \mathrm{~K}_{2} \mathrm{O}$ $\mathrm{kg} / \mathrm{ha}$ and proper plant protection measures were taken. Data was recorded for days to $50 \%$ flowering, days to maturity, plant stand maintained at harvest, shelling out turn, 100 pod weights, 100 kernel weight and sound mature kernel per cent on plot basis. Five randomly chosen plants in each genotype from each replication were collected for pod yield per plant and kernel yield per plant.

Genetic variability, heritability, genetic advance as percentage of mean and correlation were estimated. The variance of analysis was calculated as per the Panse and Sukhatme, (1985) [2]. The genotypic coefficient of variance (GCV) and phenotypic coefficient of variance (PCV) was calculated by the formula given by Falconer, (1981) [3]. Suggested the high degree of transmission of these traits from parents to progeny where the role of environment on expression is less, hence improvement of these characters could be done by selection. Heritability in broad sense was estimated according to the formula given by Singh and Choudhary, (1977) [4] and the basis for classification as low, medium high heritability was followed as per Stan Field, (1969) [5]. Correlation and path coefficient were determined by Sewall Wright, (1921) [6] to estimate type and degree of correlation between the yield and yield component traits.

\section{Results and Discussion}

Analysis of variance [Table-1] revealed significant differences among the genotypes for all the traits studied. Among all the genotypes JCG-5831 recorded 28.0 days for days to $50 \%$ flowering, whereas JCG-6696 matured early (108 days). Regarding pod yield, JCG-6703recordedhighest mean value of $2747 \mathrm{~kg} / \mathrm{ha}$ followed by JCG-6701(2562 kg/ha). The genotype JCG-6703 exhibited highest mean values for sound mature kernel $(90.00 \%)$ and shelling out turn $(76.0 \%)$ traits. For the character 100 pod weight JCG-6699 recorded highest mean values of (72grs) and least exhibited by JCG-5842 (56 g).

High phenotypic coefficient of variation (PCV) was observed for shelling percent followed by hundred kernel weights, dry pod yield/ ha, kernel yield per ha, dry haulm yield per ha and final plant stand confirming the results of John, et al., (2005) [7]. High genotypic coefficient of variation (GCV) was observed for shelling percent followed by hundred kernel weights, hundred pod weights, dry pod yield per ha, kernel yield per ha and dry haulm yield per ha. High genotypic and phenotypic coefficient of variation indicates the presence of considerable amount of genetic variability for these characters in the material studied [Table-3]. The magnitude of pcv was higher than gcv for all the characters indicating the influence of environment upon these traits.

The high estimates of heritability in broad sense were found for dry pod yield per ha (72.9), hundred pod weight (67.3) grams, duration of $50 \%$ flowering (63.6) followed by duration of maturity (62.7) days, hundred kernel weight (60.3) grams, dry haulm yield per ha (60.1) and kernel yield per ha(55.8) similar results were 
reported by Zaman, et al., (2011) [8].

The character dry haulm yield/ha (33.3) exhibited higher values for both heritability and genetic advance indicates the strong role of additive gene in expression of trait and selection could be practiced for improving this trait, whereas 100 kernel weights (22.6) and kernel yield/ha (22.6) recorded high heritability with moderate level of genetic advance indicated the role of both additive and non additive gene action. These results are comparable to the results by Jain and Ramgiri, (2000) [9]. The traits days to initial flowering (3.9), 50\% flowering (4.9), Duration of maturity (1.6), 100 pod weight (13.0) and dry pod yield/ha (15.8) have low genetic advance values and very limited scope to improve through selection as evident by recording high heritable and low genetic advance values. Final plant stand, shelling percentage and sound mature kernel recorded moderate heritability with low genetic advance values indicated the preponderance of non additive gene action on their expression, hence heterosis breeding or recurrent selection method could improve for exploitation of these characters. These results were confirmed by the findings of John, et al., (2005) [7], Zaman, et al., (2011) [8] and Jain and Ramgiri, (2000) [9] in different groundnut trials.

Table-1 Analysis of variance (Mean Squares) for yield and yield components in Groundnut

\begin{tabular}{|l|c|c|c|c|c|c|c|c|c|c|c|c|}
\hline Source of variation & Df & FPS & DFF & DFF & DM & S\% & HKW & HPW & SMK & $\begin{array}{c}\text { Kernel } \\
\text { Yield/ Ha }\end{array}$ & $\begin{array}{c}\text { Dry Haulm } \\
\text { Yield/ Ha }\end{array}$ & DPY \\
\hline Replications & 2 & 205.15 & $2.46^{* *}$ & $2.46^{*}$ & 0.42 & 23.35 & 3.62 & 0.95 & 43.48 & 36202.00 & 122341.10 & 40617.83 \\
\hline Treatments & 14 & $666.97^{*}$ & $1.47^{* *}$ & $2.91^{* *}$ & $4.27^{* *}$ & $141.93^{* *}$ & $39.33^{* *}$ & $90.54^{* *}$ & $63.27^{* *}$ & 164498.52 & 2311122.34 & $141857.68^{* *}$ \\
\hline Error & 28 & 194.22 & 0.22 & 0.46 & 0.70 & 43.64 & 7.07 & 12.59 & 16.39 & 34365.23 & 418774.77 & 15635.78 \\
\hline \hline
\end{tabular}

Table-2 Mean values of yield and yield contributing characters for 15 Groundnut genotypes.

\begin{tabular}{|c|c|c|c|c|c|c|c|c|c|c|c|}
\hline Genotype & FPS & DFF & DFF & DM & S\% & HKW(g) & HPW(g) & SMK & KY/ Ha & DHY/ Ha & DPY/ Ha \\
\hline JCG-5830 & 183 & 28 & 30 & 109 & 67 & 22 & 71 & 87. & 1529 & 2994 & 2276 \\
\hline JCG-5831 & 170 & 27 & 28 & 110 & 58 & 23 & 70 & 84 & 1274 & 3557 & 2176 \\
\hline JCG-5834 & 153 & 27 & 29 & 110 & 57 & 18 & 71 & 88 & 1367 & 3318 & 2377 \\
\hline JCG-5847 & 174 & 28 & 31 & 111 & 69 & 18 & 63 & 84 & 1336 & 3434 & 1929 \\
\hline JCG-5842 & 179 & 28 & 30 & 109 & 61 & 17 & 56 & 77 & 1173 & 2940 & 1937 \\
\hline JCG-6696 & 178 & 27 & 31 & 10 & 59 & 22 & 69 & 76 & 1214 & 3403 & 2045 \\
\hline JCG-6697 & 202 & 27 & 3 & 110 & 52 & 22 & 63 & 85 & 1257 & 3156 & 2415 \\
\hline JCG-6698 & 172 & 27 & 30 & 108 & 51 & 25 & 58 & 79 & 1158 & 4753 & 2261 \\
\hline JCG-6699 & 210 & 27 & 30 & 110 & 70 & 24 & 72 & 88 & 1522 & 5062 & 2176 \\
\hline JCG-6701 & 191 & 27 & 29 & 110 & 63 & 25 & 69 & 85 & 1605 & 5656 & 2562 \\
\hline JCG-6702 & 197 & 27 & 30 & 109 & 60 & 33 & 70 & 90 & 1440 & 3148 & 2415 \\
\hline JCG-6703 & 202 & 27 & 29 & 110 & 76 & 33 & 57 & 90 & 2088 & 3187 & 2747 \\
\hline JCG-6704 & 184 & 27 & 30 & 109 & 58 & 24 & 64 & 81 & 1310 & 3295 & 2276 \\
\hline KADIRI-6 & 194 & 27 & 29 & 110 & 68 & 31 & 71 & 88 & 1555 & 4252 & 2276 \\
\hline JCG-88 & 178 & 29 & 32 & 110 & 65 & 23 & 66 & 89 & 1487 & 4892 & 2299 \\
\hline Mean & 184.6 & 27.7 & 30.1 & 109.4 & 62.2 & 23.2 & 66.4 & 85.0 & 1421.0 & 3803.0 & 2277.8 \\
\hline C.V. & 7.5 & 1.7 & 2.3 & 0.8 & 10.6 & 11.5 & 5.3 & 4.8 & 13.0 & 17.0 & 5.5 \\
\hline C.D. 5\% & 23.3 & 0.8 & 1.1 & 1.4 & 11.0 & 4.4 & 5.9 & 6.8 & 310.1 & 1082.3 & 209.1 \\
\hline
\end{tabular}

FPS= Final plant stand, DIF= Duration of initial flowering, DFF= Duration of fifty percent flowering, DM= Duration of maturity, S\%= Shelling percentage, HKW= Hundred kernel weight, $\mathrm{HPW}=$ Hundred pod weight, SMK= Sound mature kernel, $\mathrm{KY}=$ Kernel yield, DHY= Dry haulm yieldand DPY= Dry pod yield.

\begin{tabular}{|c|c|c|c|c|c|c|}
\hline \multirow{2}{*}{ Character } & \multicolumn{2}{|c|}{ Range } & \multirow{2}{*}{ GCV } & \multirow{2}{*}{ PCV } & \multirow{2}{*}{$h^{2}$ (Broad Sense) } & \multirow{2}{*}{$\begin{array}{c}\text { Gen. Adv as } \% \text { of } \\
\text { Mean } 5 \%\end{array}$} \\
\hline & Min & Max & & & & \\
\hline Final plant stand & 153.0 & 209.7 & 6.8 & 10.2 & 44.8 & 9.4 \\
\hline Duration of initial flowering & 27.0 & 29.7 & 2.3 & 2.9 & 64.5 & 3.9 \\
\hline Duration of $50 \%$ flowering & 28.0 & 32.0 & 3.0 & 3.8 & 63.6 & 4.9 \\
\hline Duration of Maturity & 106.0 & 111.0 & 1.0 & 1.3 & 62.7 & 1.6 \\
\hline Shelling $\%$ & 51.3 & 76.0 & 9.2 & 14.0 & 42.9 & 12.4 \\
\hline Hundred kernel weight & 17.7 & 31.3 & 14.1 & 18.2 & 60.3 & 22.6 \\
\hline Hundred pod weight & 56.0 & 72.7 & 7.7 & 9.4 & 67.3 & 13.0 \\
\hline Sound mature kernel & 76.3 & 90.3 & 4.6 & 6.7 & 48.8 & 6.7 \\
\hline Dry Pod Yield/ $\mathrm{Ha}$ & 1929.0 & 2746.9 & 9.0 & 10.5 & 72.9 & 15.8 \\
\hline Kernel Yield/ Ha & 1158.2 & 2088.0 & 14.7 & 19.6 & 55.8 & 22.6 \\
\hline Dry Haulm Yield/ Ha & 2939.3 & 5655.9 & 20.8 & 26.9 & 60.1 & 33.3 \\
\hline
\end{tabular}

The phenotypic and genotypic correlations were calculated for all pairs of characters [Table-4]. At phenotypic level pod yield showed significant positive correlation with sound mature kernel (0.412), hundred kernel weights $(0.392)$, kernel yield $(0.696)$ and negative correlation for duration of initial flowering ($0.286)$ and duration of fifty percent flowering $(-0.270)$. Sound mature kernel showed significant positive correlation with hundred pod weights $(0.344)$ and shelling percent (0.383). Hundred kernel weight showed significant negative correlation with duration of maturity $(-0.507)$ and duration of initial flowering (0.379). Kernel yield per ha recorded highly significant positive correlation sound mature kernel (0.506), hundred kernel weights $(0.330)$ and shelling percentage (0.826). Dry haulm yield showed significant positive correlation with hundred kernel weights (0.366) and duration of fifty percent flowering recorded significant positive correlation with fifty percent flowering. Correlation gives the type and magnitude of association of different component traits with yield as well as nature of relationship among the characters. In the present study final plant stand, hundred kernel weights, sound mature kernel and kernel yield/ha exhibited significant positive association with dry pod yield/ha, hence selection for these traits in positive direction could improve the yield.

\section{Conclusions}

Among these fifteen entries, two entries, were recorded significantly superior yield performance viz., JCG-6701(2562) and JCG-6703(2747) and these two entries also shown highest shelling and sound mature kernel percentage. Then these two genotypes can be used in further breeding programme to improve the yield and yield contributing characters in groundnut crop. 
Gonya Nayak P., Venkataiah M., Revathi P. and Srinivas B.

Table-4 Phenotypic and Genotypic correlation coefficients among yield and other parameters in Groundnut genotypes:

\begin{tabular}{|c|c|c|c|c|c|c|c|c|c|c|c|c|}
\hline & & FPS & DIF & DFF & DM & $5 \%$ & HKW & HPW & SMK & $\mathrm{KY} / \mathrm{Ha}$ & $\mathrm{DHY} / \mathrm{Ha}$ & DPY/Ha \\
\hline FPS & $\mathbf{P}$ & 1.000 & -0.073 & 0.006 & -0.089 & 0.169 & 0.245 & -0.056 & 0.221 & 0.257 & -0.060 & 0.250 \\
\hline DIF & $P$ & & 1.000 & $0.682^{* *}$ & 0.261 & 0.138 & $-0.379^{*}$ & -0.184 & 0.012 & -0.068 & 0.082 & -0.286 \\
\hline \multirow[t]{2}{*}{ DFF } & $\mathbf{P}$ & & & 1.000 & 0.066 & 0.057 & -0.219 & -0.213 & -0.123 & 0.120 & -0.048 & -0.270 \\
\hline & G & & & 1.000 & 0.208 & 0.021 & -0.281 & -0.266 & -0.216 & -0.212 & -0.003 & -0.333 \\
\hline DM & $P$ & & & & 1.000 & -0.043 & $-0.507^{* *}$ & 0.166 & 0.068 & -0.018 & 0.022 & 0.024 \\
\hline \multirow[t]{2}{*}{$\mathrm{S} \%$} & $P$ & & & & & 1.000 & 0.153 & 0.168 & $0.383^{* *}$ & $0.826^{* *}$ & 0.223 & 0.179 \\
\hline & G & & & & & 1.000 & 0.055 & 0.018 & 0.623 & 0.755 & -0.040 & 0.118 \\
\hline \multirow[t]{2}{*}{ HKW } & $P$ & & & & & & 1.000 & 0.208 & 0.213 & $0.330^{*}$ & $0.366^{*}$ & $0.392^{* *}$ \\
\hline & G & & & & & & 1.000 & 0.389 & 0.472 & 0.303 & 0.394 & $0.437^{* *}$ \\
\hline \multirow[t]{2}{*}{ HPW } & $P$ & & & & & & & 1.000 & $0.344^{*}$ & 0.108 & 0.199 & 0.037 \\
\hline & G & & & & & & & 1.000 & 0.454 & -0.014 & 0.227 & -0.013 \\
\hline $\mathrm{KY} / \mathrm{Ha}$ & G & & & & & & & & & 1.000 & 0.035 & $0.739^{* *}$ \\
\hline \multirow[t]{2}{*}{$\mathrm{DHY} / \mathrm{Ha}$} & $P$ & & & & & & & & & & 1.000 & 0.198 \\
\hline & G & & & & & & & & & & 1.000 & 0.134 \\
\hline \multirow[t]{4}{*}{ DPY/Ha } & $P$ & & & & & & & & & & & 1.000 \\
\hline & G & & & & & & & & & & & 1.000 \\
\hline & \multicolumn{3}{|c|}{ Significance levels } & 0.05 & 0.01 & 0.005 & 0.001 & & & & & \\
\hline & \multicolumn{3}{|c|}{ If correlation 'r' } & 0.293 & 0.380 & 0.411 & 0.474 & & & & & \\
\hline
\end{tabular}

Application of research: High yielding groundnut genotypes can be used for further breeding programme as female parent or male parent based on objective of the project.

\section{Research Category: Genetic Analysis}

\section{Abbreviations:}

GCV: Genotypic coefficient of variation

PCV: Phenotypic coefficient of variation

Acknowledgement / Funding: Author thankful to Professor Jayashankar Telangana State Agriculture University, Rajendranagar Mandal, Hyderabad, 500030 , Telangana

\section{*Chairperson of research: Dr P. Gonya Nayak}

University: Professor Jayashankar Telangana State Agricultural University, Rajendranagar Mandal, Hyderabad, 500030, Telangana

Research project name or number: Development of High yielding groundnut varieties suitable for Telangana state.

\section{Author Contributions: All author equally contributed}

Author statement: All authors read, reviewed, agree and approved the final manuscript

\section{Conflict of Interest: None declared}

Ethical approval: This article does not contain any studies with human participants or animals performed by any of the authors.

\section{References}

[1] Mannand Senegal FAO. (2001) FAO Bulletin of Statistics, 2(2): 63.

[2] Panse V.G. and Sukhatme P.V. (1985) Statistical methods Agricultural Workers. ICAR, New Delhi. pp. 235-246.

[3] Falconer D.S. (1981) Biometrical techniques in plant breeding. Kalyani Publishers, New Delhi.

[4] Singh R.K. and Choudhary B.D. (1977) Biometrical Methods in Quantitative Genetic Analysis. Kalyani Publishers, New Delhi.

[5] Stan field W.D. (1969) Theory and Problems of Genetic. Mc. Graw Hill,
New York

[6] Sewall Wright (1921) Biometrical techniques in plant breeding. Kalyani Publishers, New Delhi.

[7] John K., Vasanthi R.P., Venkateswarlu O. and Haranath Naidu P. (2005) Legume Res., 28 (3): 189 - 193.

[8] Zaman M. A., Tuhina-Khatun M., Ullah M. Z., Moniruzzamn M. and Alam K. H. (2011) A Scientific Journal of Krishi Foundation The Agriculturists, 9(1\&2), 29-36.

[9] Jain P.K. and Ramgir S.R. (2000) Annals of Agricultural Research, 15: 45-49. 